\title{
Sports Industry Management in Demak Regency
}

\section{Amad Fa'is ${ }^{1 *}$, Tri Nurharsono ${ }^{2}$, Lulu April Farida ${ }^{3}$, Agus Widodo Suripto ${ }^{4}$}

${ }^{1 * 234}$ Department of Physical Education, Health and Recreation, Faculty of Sport Sciences, Universitas Negeri Semarang, Indonesia

\begin{abstract}
Article History:
Received: 2 April 2021

Accepted: 24 April 2021

Published: 26 April 2021
\end{abstract}

\section{Keywords: \\ Survey; Management; Industry; Sport}

\begin{abstract}
The purpose of the research to know the description of management includes planning, organizing, driving, and supervision of sports industry management in Demak regency. Methods This research is a survey research using qualitative descriptive approach. The result of this research is 1) The planning process done by sports industry in Demak Regency has been run in accordance with the management function, 2) The management of sports industry in Demak Regency is still lacking, because the whole of sports industry does not have organizational structure so there are many double function to the owner and employees, 3) The management of sports industry in Demak Regency is quite good, because the communication between owner, manager and employee is good, employees also execute manager's orders well in accordance with their duties, 4) Sports industry supervision management in Demak Regency is good, because all owners always supervise their employees.
\end{abstract}

\section{How To Cite:}

Fa'is, A, Nurharsono, T, Farida, L. A, \& Suripto, A. W. (2021). Sports Industry Management in Demak Regency. Indonesian Journal of Sport Management, 1(1), 50-57. https://doi.org/10.31949/ijsm.v1i1.991

Corresponding author: Amad Fa'is, Department of Physical Education, Health and Recreation, Faculty of Sport Sciences, Universitas Negeri Semarang, Central Java, Indonesia

Email: amadfais@gmail.com 


\section{INTRODUCTION}

Sport is an activity to train a person's body, not only physically but also spiritually, exercise is also very beneficial for the health of the body, by exercising the body's metabolism to be smooth so that the distribution and absorption of nutrients in the body becomes more effective and efficient. This makes people aware of the importance of health by exercising, people begin to flock to the sports they like both young people, parents, men and women, they are very excited to exercise in order to maintain their physical, spiritual and fitness health. Busy urban life demands physical fitness in order to be able to do activities properly and to maintain health (Setyawan, 2015). Nowadays, the role of sport is increasingly important and strategic in the life of a global era that is full of change, competition and complexity (Apriyanto, et. atl., 2015).

Despite the unique aspects of Asian sports business, relatively few studies on sports economics and management have attempted to empirically study the industry in the region (Lee and Watanabe, 2019). Sports management aspires to assert an ideal self-realization image with a certain physically active lifestyle (Girginov, 2010). Sport today penetrates into all spheres of life of people, forms relations with the state, creating a specific sphere for running a business. Sport also represents one of the most important spheres of entrepreneurial activity that provides, on the one hand, the engagement of a large number of people in the branches of the sports industry, while on the other hand, these branches of entrepreneurship fill state and local budgets at the expense of taxes, which to some extent allows the state to solve various social problems. Consequently, modern sports, and therefore the sports industry, are activities of public interest for each state. That is why the state should influence the creation of new conditions for the further development of sports (Solncev, 2012; Savić, et. al., 2017).

The sport industry is a large and fast-growing industry. The U.S. market accounted for as much as \$400-435 billion in 2012 (Plunkett's Sport Industry Almanac; Ko, 2013). The conventional definition of the sport industry inclu- des "the products offered to its buyers are sport, fitness, recreation, or leisure-related and may be activities, goods, services, people, places, or ideas" (Pitts \& Stotlar, 1996; Ko, 2013). Today, the sports market is extending its boundaries by encompassing the entertainment industry and becoming a global cultural phenomenon (Gillentine, 2012; Ko, 2013).

In exercising, of course, requires facilities and infrastructure. The higher the public's interest in sports, the higher the demand for facilities and infrastructure to fulfill their needs in exercising. This is certainly not wasted by other people to take advantage of these opportunities in creating new jobs in the sports industry to meet consumer demand.

National Sports System (SKN) 2005, it is explained that: the sports industry is a business activity in the field of sports in the form of goods and / or services (Undang-Undang Sistem Keolahragaan Nasional). The sports industry in the field of goods is a physical product that is visible or tangible so that it can be given to the buyer, so that it can be transferred from the seller to the buyer. Examples of the sports industry in the field of goods include the sale of martial arts uniforms, sports team uniforms (jersey) and sales of sports equipment. 
The sports industry in the service sector is any activity or service work that is offered from one party to another. examples of the sports industry in services such as futsal court rental services and fitness massage services (massage). The supporting factors for the advancement of the sports industry are created from the quality of human resources who have knowledge and experience in an area of ability that is mastered. Aspects of the sports industry are supported by management from various fields and have a leader who is able to understand each area that he manages himself. One of the roles of the sports industry, among others, is to encourage rural areas to be more developed, by absorbing labor, increasing community income, and spreading the industry (Prakoso, 2015).

Some of the many sports industries in the field of goods and services that are currently in the business of clothing convection, sales of sports equipment, rental of sports facilities and infrastructure and many more. In addition to supporting norms in society, sports clothing is also very important in adjusting clothing to the sports field. Therefore, the sports industry in the manufacture of various types of sports clothing is growing very rapidly in all levels of society, such as the school environment, sportsmen, adults, and even children who are fond of sports have their own clothes in their activities. The important thing besides sports clothing is sports equipment to support activities. Sports that develop in society have great potential in selling sports equipment that are tailored to the development of each separate sport to maximize these sports activities.

People who are starting to become aware of the importance of sports in order to maintain physical and spiritual health as well as to maintain fitness have made them much involved in certain sports, this has also greatly influenced the development of the sports industry. In the relationship between each sport and the sports industry, it is very closely related, given the need for various facilities and infrastructure to maximize these activities. With a wide variety of models and designs that are desired to describe the characteristics of a particular sport, this will have a big impact on the development of the sports industry, especially in the goods and services industry, given the need for the identity of a sport that annually accepts new members. Quality and quality that are not less competitive with other products will provide comfort in their use.

In sports, of course, it requires a place or field to maximize sports activities, but nowadays the difficulty of land for exercising has made rental services for sports venues and sports equipment more widespread in society, this has made the rental of sports facilities and infrastructure a promising industry. With the rental of facilities and infrastructure, people can channel their hobbies without thinking about finding a place to exercise, this makes the rental of facilities and infrastructure very vital in the community.

A good sports industry will not develop without good management in it, because good management will contribute significantly to the development of the industry. The management division, such as the functions of planning, organizing, directing, and controlling each other, is related to supporting the development of a sports industry. The sports industry, both goods and services, is well known in Indonesia. However, the management on average is still traditional and lacks attention, where the owner still holds quite a lot of roles. In the goods industry, usually the owner still has many roles, as a shopper, as a marketing, as a guard and 
many more. Very few in the sports industry use modern management systems for a variety of reasons. Likewise, in the service sector, it is not known whether the place management business management supports aspects, one of which is how to promote, organize management, how to serve customers, the feasibility level of facilities and infrastructure and whether or not consumers are satisfied with these service providers.

Based on the description above, that the sports industry greatly influences the development of sports in society, in reality the sports industry is underdeveloped to meet the needs of society. So, from the authors are interested in examining research related to the management of the sports industry in Demak Regency in order to mine knowledge about management patterns that can be applied to a sports facility and infrastructure packaged in an effort to improve the economy.

\section{METHOD}

The method used in this research is descriptive qualitative method. This research was conducted in the Demak Regency area. The location in the research of the Sports Industry Management Survey in Demak Regency. The place for the sports goods and services industry in Demak Regency. The research objectives are all elements under study. The target of this study is the manager as a structured interview respondent which includes: planning, organizing, directing and monitoring.

In this case the variables used are planning, organizing, directing and monitoring. In the data collection method, the first step taken is to first adjust it to the purpose of the information required. Then determine the focus of the problem to be reviewed in the research. After that, what is done is determining and scheduling interviews, observing the object of research, and taking the required documentation of information. Types and sources of data used are interviews and documentation.

To determine the validity (trustworthiness) of data, an inspection technique is needed. The implementation of the inspection technique is based on a number of certain criteria. There are four criteria used, namely the degree of trust (credibility), transferability (transferability), dependability (dependability), and certainty (confirmability).

The initial conclusions put forward are still temporary, and will change if there is no strong supporting evidence found at the next data collection stage. But if the conclusions put forward at an early stage are supported by valid and consistent evidence when the researcher returns to the field to collect data, then the conclusions put forward are credible conclusions. So that the conclusion in this research is that it will be able to find out the extent of the management of the sports industry in Demak Regency to date, and then suggestions will be included if needed.

\section{RESULT AND DISCUSSION}

\section{Planning}

Based on this research, it can be seen that the planning process carried out by all sports industries is good because it has clear objectives. Strategic planning is a development process and a process to analyze the mission of the sport organization, the overall purposes, general strategies and allocations of its resources. This is the 
part of the strategic management and in its based it is long term defined, directed to problem solving. Precisely said the definition that most clearly describes the strategic planning is the process of defining the most important purposes of the sport organization as well as the strategy that helps to activate all disposable resources toward performing purposes process (Ilić, 2013).

\section{Organizing}

The organization in all sports industries is good enough and is appropriate for its function, but all sports industries do not yet have a written organizational structure. Identifying and grouping the work to be performed on individual projects is a very different proposition from doing so in permanent organizations. Projects are temporary organizations, with several distinctive phases, often with quite different people contributing to each phase. This typically involves quite different approaches to effectively structuring the work for each phase, and organizing resources accordingly (Stretton, 2015).

In an overview of management organizing, it was recognized that most, if not all, permanent organizations undertake projects, but that there were two quite different types that do so, namely production-based organizations and projectbased ones. Projects in the former may be undertaken in-house, or by an external project provider, or a mixture of both. Those undertaken in-house are typically done using a matrix organizational format (Stretton, 2015).

\section{Directing}

The function of directing sports industry managers in Demak Regency is good, managers motivate and direct employees by using kinship so that employees are easy to accept, besides that managers also give bonuses if they meet targets and there is also an agenda for trips for employees. The need to face new challenges in a globalized world requires leaders to accept a complex role which involves combining continuity with innovation, based on a solid foundation of social values, ethical principles and the practice of integrating groups of professionals from different areas (Javier, et. al., 2015).

In comparison with typical traditional leadership, there have emerged new models of leadership much more dynamic and in step with reality. Thus, we see other types of leadership, for example, the transformational model which demonstrates positive correlations not only among different individual variables in the leader (ethics, emotional management, knowledge-building, etc.), but also with results at the organizational level (better performance, higher team satisfaction) (Javier, et. al., 2015).

\section{Controlling}

Managers always make observations and checks on employee performance as well as on facilities that need improvement, the intensity of supervision carried out by managers varies, from once every 3 days to every day. It is concluded that the supervision by the manager is quite good. Specific for controlling in the sport management are the concern for the transparency of the analyzes, considerations and evaluations of the situations and the economic perspective on some problems, situations and initiatives from the sports organization. In addition, specific for 
controlling in sports management is the combination of management duties and even multidisciplinary tasks (Guță, 2019).

Achieving the objective of implementing a complete and balanced concept of controlling within sports organizations, accepted on a sustainable basis at all levels and in all sectors and which brings added value usually lasts between one and three years, but this aspect is only considered as general standard, being relevant this time also the particularities of each individual situation. A successful implementation of controlling in sports management can only be achieved by a coalition between the promoters holding positions of power and the specialized ones, through their joint efforts being possible to overcome both the cognitive barriers, as well as those of will and competence (Guță, 2019).

Sports marketing belongs to sports science and it explains the factors of the sports industry. According to Milojević, sport is a domain of human activity in which marketing plays an important role, since many sports events are mass media events of the highest level (Milojević, 2003; Savić, et. al., 2017). The basis of each sports marketing attempt is reflected in the satisfaction of the buyer (the market) of sports products through loyal competition. People buy things for a variety of reasons, and marketing is the means to gain insight into the needs of the target group and to satisfy these needs with ready-made products. Sports marketing, in the sphere of economy is connected to the manufacture of sports products and provision of services and their supply and demand. Its significance and importance in the sports industry is invaluable. Then rightly ask the question of what constitutes a sports product.

Odio (Andrew, et. al., 2019), argues that time is an important factor that is often neglected in the development of theories related to sports management. Time, for example, affects the seasons and production factors that accompany various sports as well as contexts such as gym attendance and recreational sports.

Certainly, sports products include results, final products, services and manifestations or sports events (Tomić, 2001; Savić, et. al., 2017). Marketing has its place in all forms of planning. The final product in sport is the ultimately prepared athlete, the result and the win. This is the effect of a vigorous training process which often in practice contains elements of illegal activities, but also abuse. The emphasis is on the fact that positive and legal means are predominant, although in practice there are cases, especially when it comes to larger competitions that illegal substances are used and certain abuse in sport can be identified. Athletes, quite often as a result of inexperience (nutritional information, side effects, dosing, means of use...), do not even know how to use certain illegal substances. The sports industry has found its roots in both one type of behavior and the other.

\section{CONCLUSION}

Based on the results of research on a survey on the management of the sports industry in Demak Regency, the following conclusions can be drawn: 1) The planning management of the sports industry in Demak Regency is sufficient in the provision of facilities and facilities and infrastructure. All industries have almost the same objectives, namely doing business and facilitating and advancing sports in Demak Regency. 2) The organizational management of the sports industry in Demak Regency is still lacking, because the entire sports industry does not yet have an 
organizational structure so that there are many dual functions for owners and employees. 3) The management of the sports industry in Demak Regency is sufficient because communication between owners, managers and employees has been going well, employees also carry out manager's orders properly according to their duties. 4) Supervision management of the sports industry in Demak Regency is good, because all owners always supervise it every few times a day or every day to see the performance of employees and the feasibility of facilities and infrastructure.

\section{ACKNOWLEDGEMENT}

I would like to express my deepest gratitude to companies in the field of sports who have agreed to be willing to be the object of this research.

\section{REFERENCES}

Andrew, D. P. S., Grady, J \& Kim, S. (2019). Is There Anything Unique About Sport Management? An Introduction to the JGSM Special Issue on "The Uniqueness of the Sport Context". Journal of Global Sport Management. https://doi.org/10.1080/24704067.2019.1641831

Apriyanto, A. A., Priyono, B., \& Supriyono. (2015). Survei Manajemen Wahana Outbound di Pancasan Dream Land Park Kabupaten Banyumas Tahun 2013. Journal of Physical Education, Sport, Health and Recreations, 10(2), 680-685. https://doi.org/10.15294/active.v2i10.2025

Guță, E. L. (2019). Importance in The Organization of Controlling in Sports. Annals of the „Constantin Brâncuşi" University of Târgu Jiu, Economy Series, Issue 6, 319-324

Girginov, V. (2010). Culture and the Study of Sport Management. European Sport Management Quarterly, 10(4), 397-417. DOI: 10.1080/16184742.2010.502741

Ilić, R. (2013). Strategic Planning at Sports Organizations. Journal of Process ManagementNew Technologies, International, 1(4), 113-121.

Javier, I. O., Alfonso, C. R., \& José Luis, C. M. (2015). Sports Management, Leadership in the Organization. Journal of Physical Education and Sports Management, 2(2), 56-65. http://dx.doi.org/10.15640/jpesm.v2n2a5

Ko, Y. J. (2013). Sport Management and Marketing: Overview and Recommendation for Future Research. International Journal of Sport Science, 9(33), 205-207. doi:10.5232/ricyde2013.033

Lee. H. L., \& Watanabe, N. (2019). Sports Economics and Management of Asian Sports Business. Journal of Global Sport Management, 1-7. https://doi.org/10.1080/24704067.2018.1553023

Prakoso, A. I. (2015). Survei Manajemen Industri Olaharaga Arung Jeram di Rainbow Rafting Kabupaten Pemalang Tahun 2014. Journal of Physical Education, Sport, Health and Recreations, 12(4), 2214-2218.

Savić, Z., Ranđelović, N., Stojanović, N., Stanković, V, \& Šiljak, V. (2017). The Sports Industry and Achieving Top Sports Results. FACTA UNIVERSITATIS Series: Physical Education and Sport, 15(3), 513-522. https://doi.org/10.22190/FUPES1703513S 
Setyawan, B. Y.P. (2015). Survei Manajemen Sarana dan Prasarana di Stadion Jatidiri Kota Semarang Pada Tahun 2013. Journal of Physical Education, Sport, Health and Recreations, 4(4), 1753-1758. https://doi.org/10.15294/active.v4i4.4858

Stretton, A. (2015). Management Organizing Function and Activities. PM World Journal (Management Organizing Function and Activities Series on General Management and PM), 4(10), 1-11

Undang-Undang Republik Indonesia Nomor 3 Tahun 2005 Tentang Sistem Keolahragaan Nasional. 23 September 2005. Lembaran Negara Republik Indonesia Tahun 2005 Nomor 89. Jakarta

Undang-Undang Republik Indonesia Nomor 3 Tahun 2005 Tentang Sistem Keolahragaan Nasional. 23 September 2005. Tambahan Lembaran Negara Republik Indonesia Nomor 4535. Jakarta

\section{Copyright holder:}

(C)(2021) Amad Fa'is, Tri Nurharsono, Lulu April Farida, Agus Widodo Suripto

First publication right:

Indonesian Journal of Sport Management

This article is licensed under: 